\title{
Separated Powers in the United States: The Ideology of Agencies, Presidents, and Congress
}

\author{
Joshua D. Clinton Vanderbilt University \\ Anthony Bertelli University of Southern California \\ Christian R. Grose University of Southern California \\ David E. Lewis Vanderbilt University \\ David C. Nixon University of Hawaii
}

\begin{abstract}
Government agencies service interest groups, advocate policies, provide advice to elected officials, and create and implement public policy. Scholars have advanced theories to explain the role of agencies in American politics, but efforts to test these theories are hampered by the inability to systematically measure agency preferences. We present a method for measuring agency ideology that yields ideal point estimates of individual bureaucrats and agencies that are directly comparable with those of other political actors. These estimates produce insights into the nature of the bureaucratic state and provide traction on a host of questions about American politics. We discuss what these estimates reveal about the political environment of bureaucracy and their potential for testing theories of political institutions. We demonstrate their utility by testing key propositions from Gailmard and Patty's (2007) influential model of political control and endogenous expertise development.
\end{abstract}

$\mathrm{F}$ or democratic government to be effective, it must rely on administrative officials to make and implement policy. While the Constitution barely describes an administrative apparatus, the departments and agencies created by Congress and the president play a key role in the politics and policy of the United States. The growth in the size, role, and complexity of government activity has forced elected legislators and presidents to increasingly rely on administrative officials to set policy agendas and make and implement policy decisions. With the increased political role of administrative actors, scholars have raised many important questions about federal executives and their agencies. Do they follow their own views about what policy should be or do they pursue the policy goals of the president, the courts, Congress, or the public more generally (see, e.g., Carpenter 2001; McCubbins, Noll, and Weingast 1987, 1989; Weingast and Moran 1983; Whitford 2005; Wood and Waterman 1994)? When legislators and presidents delegate authority to these administrative officials, how do they take into account agency preferences (see, e.g., Bendor and Meirowitz 2004; Bertelli and Feldmann 2007; Boehmke, Gailmard, and Patty 2005; Epstein and O'Halloran 1999; Huber and Shipan 2002)? When, and to what extent, do elected officials impose ex ante and expost constraints on bureaucrats (Aberbach 1990; McCubbins, Noll, and Weingast 1987, 1989; McCubbins and Schwartz 1984; Moe 1985a)?

These questions are central to the study of American politics and political institutions more generally. Yet the important theorizing that has occurred to answer these

Joshua D. Clinton is Associate Professor of Political Science and Co-Director of the Center for the Study of Democratic Institutions at Vanderbilt University, Commons Center, PMB0505, 230 Appleton Place, Nashville, TN 37203-5721 (josh.clinton@vanderbilt.edu). Anthony M. Bertelli is Associate Professor and the C. C. Crawford Chair in Management and Performance at the University of Southern California, RGL 201D, 650 Childs Way, Los Angeles, CA 90089 (bertelli@usc.edu). Christian R. Grose is Associate Professor of Political Science at the University of Southern California, Dornsife College of Letters, Arts, and Sciences, 327 Von KleinSmid Center, Los Angeles, CA 90089-0044 (cgrose@usc.edu). David E. Lewis is Professor of Political Science and Co-Director of the Center for the Study of Democratic Institutions at Vanderbilt University, Commons Center, PMB0505, 230 Appleton Place, Nashville, TN 37203-5721 (david.e.lewis@vanderbilt.edu). David C. Nixon is Associate Professor of Public Policy and Public Administration at the Univesity of Hawai' i, Public Policy Center, College of Social Sciences, Saunders Hall 723, 2424 Maile Way, Honolulu, HI 96822 (dnixon@hawaii.edu).

An earlier version of this article was presented at the 2008 annual meeting of the American Political Science Association, Boston. We thank the Princeton Survey Research Center for careful data collection and essential advice. We thank Michael Herron for helpful comments. Ideal point estimates and other data from this article are available for download at http://www.vanderbilt.edu/csdi/, http://www.usc.edu/schools/sppd/idealpoints, http://www.christiangrose.net, or http://www2.hawaii.edu/ dnixon/SFGS/.

American Journal of Political Science, Vol. 00, No. 0, October 2011, Pp. 1-14

(C) 2011, Midwest Political Science Association

DOI: $10.1111 / \mathrm{j} .1540-5907.2011 .00559 . x$ 
questions has not been accompanied by comparable empirical testing. Efforts to test theories of delegation, separation of powers, and bureaucratic control are hampered by the inability to systematically measure the preferences of administrative agencies in a way that is comparable to other political actors. While sophisticated estimates of legislative, presidential, and judicial preferences have been developed, no comparable measure of both appointee and careerist bureaucratic preferences exists (Bailey 2007; Epstein et al. 2007; McCarty and Poole 1995; Poole 1998; see, however, Bertelli and Grose 2009, 2011; Nixon 2004). We have very little systematic information about which agencies are liberal or which agencies are conservative and what effects these differences have for agency design, delegation, political oversight, or judicial deference (Bertelli and Grose 2009, 2011; Clinton and Lewis 2008; Nixon 2004). This is an important limitation for which we provide a remedy.

We administered a survey to 7,448 federal executives, and we use methods similar to those used to assess citizen and candidate positions (e.g., Bafumi and Herron 2010; Jessee 2009,2010 ) to measure the policy preferences of bureaucrats and agencies on the same scale as measures of policy preferences for the other political branches. We use the stated preference of federal executives about key votes in Congress to estimate ideal points for these executives on the same space as legislators and the president. We then aggregate the individual ideal points into a measure of agency preferences.

We describe the survey and method we use to assess the preferences of individual bureaucrats and federal agencies in the first two sections. The third section explores the individual-level estimates and characterizes the relationship of careerists and appointees relative to the political environment surrounding the bureaucracy, and the fourth confronts the task of measuring agency preferences and presents a measure that is directly comparable to the preferences of members of Congress and the president. The fifth section uses the agency-level estimates to test key propositions from Gailmard and Patty's (2007) influential model of political control and endogenous expertise to demonstrate their usefulness for evaluating existing theories of American politics and political institutions. We conclude by discussing how the estimates can help advance our understanding of American politics and political institutions more generally.

\section{Measuring Agency Ideology}

In administrative agencies, it is not clear where preferences reside or how we might aggregate individual preferences along with other features of agencies that might have ideological content into an estimate of agency ideology. To date, there have been four main approaches to measuring the ideology of agencies. Each method has its strength, but many of them rely on subjective assessments, have problematic assumptions about agency preferences, or are hard to compare across institutions. The first approach uses judgments about agency ideology based upon objective information and subjective judgment. Some scholars classify agencies as liberal or conservative on the basis of the mission of the agency (e.g., regulation, defense) or whether the agency has a mission closer to the policy commitments of one political party (e.g., Gilmour and Lewis 2006). Clinton and Lewis (2008) try to systematize the subjective assessments by conducting an expert survey on agency preferences, but the usefulness of the approach depends on the accuracy of scholarly judgments. Problems arise if experts are limited in their knowledge of lesser-known agencies or make similar mistakes in categorizing agencies as liberal or conservative (e.g., Defense Nuclear Facilities Safety Board). Moreover, the resulting estimates are not easily compared to the estimated preferences of other political actors such as the president or Congress.

A second common approach to measuring agency preferences uses information about current or past political configurations to determine agency ideology. For example, some code agencies as liberal or conservative based upon whether they are created by Democratic or Republican presidents or congresses (Gilmour and Lewis 2006). Others code agencies as liberal or conservative based upon the party affiliation of the president or the appointees in each agency (see, e.g., Cohen 1986; Epstein and O'Halloran 1999; Huber and Shipan 2002). Coding agencies by the politics at the time they were created implicitly forces one to assume that agencies such as the Council of Economic Advisers or Office of Personnel Management (unified Democratic control) are more liberal than agencies such as the Consumer Product Safety Commission or the Environmental Protection Agency (divided party control). Such assumptions are extremely imprecise and contrary to other scholarly assessments of agency ideology (Clinton and Lewis 2008). Coding agencies according to contemporaneous politics faces similar difficulties. The presence of a Republican administration does not imply that all agencies are conservative. Nor does an appointee from the president's party necessarily share the president's preferences or completely determine the policy preferences of the agency. Indeed, agency structures, the civil service, and congressional involvement ensure that agencies do not reliably share either the president's 
or appointees' views (see, e.g., Aberbach and Rockman 1976; Bertelli and Feldmann 2007; Maranto and Hult 2004).

A third approach uses surveys to evaluate the ideology of the executive branch officials (Aberbach and Rockman 2000; Golden 2000; Maranto 1993a, 1993b; Maranto and Hult 2004; Meier and Nigro 1976; Michaels 1997). This work has provided important insight into the diversity of political views over time, across executive types, and among agencies with broadly different missions (defense, social welfare, regulation). Using such data for testing separation of powers models or theories of political control, however, is difficult since the survey samples are frequently too small to allow comparison across agencies, and the surveys provide no means of developing comparable ideology measures across agencies or branches.

A final common approach to measuring agency preferences relies on observed behavior, such as commission votes or statements of agency officials, to estimate the ideal points of agency appointees. Some scale the votes of commissioners to develop measures of ideology (Moe 1985b; Nixon 2004; Snyder and Weingast 2000). One difficulty with this approach is that the number of persons who have served in both agencies and Congress is extremely limited and officials in administrations (as opposed to commissions) do not vote in the same way that commissioners do. Bertelli and Grose $(2009,2011)$ use the public positions of cabinet secretaries on votes in Congress to estimate executive preferences across time and institutions. While their focus on cabinet secretaries is novel, their measures only include department-level appointees, as lower-level bureaucrats rarely take public positions on roll calls in Congress.

Limitations in the four existing approaches to measuring agency ideology necessitate the continued search for new measures. To illuminate the political environment and facilitate empirical tests, a new measure of the policy preferences of an agency would ideally permit direct comparisons to the policy preferences of other political actors. This requires an ability to directly compare the opinions of bureaucrats to the opinions of other critical political actors on a common set of issues. Moreover, it would be expansive enough so as to examine potential variation both across and within agencies. Ideally, a measure would allow scholars to not only examine the effects and consequences of variation in agency preferences, but also consider the causes and consequences of variation within the hierarchy of a given agency.

\section{Estimating Agency Ideology Using Federal Executives' Opinions}

Our analytical strategy entails two components: first, survey individual federal executives - both appointees and careerists - within departments and agencies in such a way so as to directly compare the policy opinions of federal executives to the policy opinions of legislators and the president, and second, aggregate the opinions of the executives into estimates of agency ideology. We survey agency officials to obtain data on the "votes" of policymaking bureaucratic officials. By asking federal executives how they would have voted on issues that came to a vote in the previous Congress, it is possible to use the responses to relate the preferences of the executives to members of Congress. Since our survey respondents can be thought of as "voting" on the same issues as members of Congress, it is possible to use the set of common issues to measure the opinions of respondents and federal legislators in a manner that is directly comparable (Bafumi and Herron 2010; Jessee 2009, 2010). ${ }^{1}$

In the fall-winter of 2007-08 we conducted the Survey on the Future of Government Service. The survey was sent to 7,448 federal administrators and program managers (both career and appointed) in the various departments and agencies. The target population included cabinet secretaries, deputy, under-, and assistant secretaries, as well as independent agency heads, bureau chiefs, general counsels, and key deputies in the government bureaucracy. The overall response rate was $33 \%$, and the sample is generally representative of the population of federal executives. Higher-level political appointees are somewhat underrepresented in the sample relative to the population, but we confront this issue in the fourth section when discussing the measurement of agency ideal points. ${ }^{2}$ (The appendix contains a full discussion of the survey methodology.)

${ }^{1}$ Unlike the costs of public positioning in legislative roll-call voting (Bertelli 2010; Bertelli and Grose 2006; Clinton 2006; Grose 2011, 64-78; Poole and Rosenthal 1997), judicial decision making (Bailey 2007; Martin and Quinn 2002), or presidential position taking (Bailey 2007; Bertelli and Grose 2007; Poole and Rosenthal 1997; Treier 2010), the political costs of responding to a confidential, academic survey are low.

${ }^{2}$ We have responses from 259 political appointees (102 Senateconfirmed appointees) and 2,021 career professionals. Of the approximately 550 policy-relevant Senate-confirmed appointees, this amounts to a $19 \%$ response rate. There are 131 appointed members of the Senior Executive Service who responded out of approximately 700 total (19\%), but not all of the 700 appointees in the SES are administrators or program managers. 
One concern is whether Democrats are more likely to respond to the survey than Republicans because of increased dissatisfaction with the Bush administration. While $59 \%$ of the respondents are Democrats, this does not strike us as an implausible estimate of the overall population of bureaucrats. To determine whether there might be systematic nonresponse, we compared the partisan response rate of executives serving in the Washington, DC, area to voter registration data in the DC metro area. We used a private firm to find home addresses for as many executives in our population in the Washington, DC, metropolitan area as possible (primarily through the matching of unique names) and examined the voter registration information for those respondents whose home addresses we were able to secure. ${ }^{3}$ This information is publicly available in Maryland and the District of Columbia, but there is no party registration in Virginia. In total, $57.4 \%$ of executives (both respondents and nonrespondents) living in these locations were registered Democrats. Compared to the sample of registered voters, neither Democrats nor Republicans nor Independents participated at a higher rate than the voter registration percentages would suggest $\left(\chi^{2}=1.7,0.9\right.$, and 0.37 , respectively).

To measure the ideology of the responding executives, we use questions based on 14 votes taken in the House or Senate in 2006. To identify the votes, we use the National Journal's list of 187 key votes dealing with economic, social, or foreign policy to select a mix of economic and social issues that were easy to read and interpreti.e., no votes on procedural issues or votes with unclear substantive implications. We selected seven votes in each chamber. ${ }^{4}$

We did not ask the executives about issues directly related to the activities of the bureaucrats themselves to minimize the extent to which possible interactions with Congress or the president might affect the bureaucrats' opinions on the issues. Asking about issues specific to the agency would not only make comparisons across agen-

${ }^{3}$ Out of 7,448 names, 2,918 were matched with home addresses. Of these 2,918 names, 415 were in the District of Columbia, 677 in Maryland, and 1,622 in Virginia. Out of 1,092 persons with addresses in the District of Columbia and Maryland, we were able to get voter information on $717(66 \%)$. The remainder is comprised of those who are registered Republicans $(24.02 \%)$ or did not register with either major party (18.58\%).

${ }^{4}$ The appendix contains the votes and question wording. To ensure that the selected votes would adequately partition the ideological space and provide enough information to distinguish between members, we made sure that the 14 votes selected all had statistically significant item discrimination parameters in a pooled analysis of the House and Senate using all roll calls and the statistical model of Clinton, Jackman, and Rivers (2004). cies difficult, but it would also risk contaminating the responses with strategic considerations. We sought to use a set of items that would allow us to compare the ideological composition of the sincere preferences of the bureaucracy to that of Congress and the president.

To be clear, the opinions we gather do not necessarily represent what those executives would do were they empowered to make public policy, nor does it necessarily provide a complete description of the policy space in which the agency might work. However, what the estimates provide is an ability to directly compare and contrast the opinions of critical actors in the national government on a broad spectrum of ideological issues. Describing how the ideology of bureaucrats and agencies compare to political actors in terms of general ideological disposition helps provide a more comprehensive picture of the national bureaucracy and reveals how the preferences of its members compare to the preferences of elected officials on general issues. In fact, combined with the estimates of citizen preferences produced by Bafumi and Herron (2010), the estimates help provide an extensive picture of the national political scene.

Given the opinions of the bureaucrats on the votes we collect using the survey, estimating directly comparable ideal points is relatively simple. We use every vote in the House and Senate to estimate congressional ideal points. We use all public positions taken on those votes to estimate the location of President Bush, and we use votes on four controversial conference reports to "bridge" estimates in the House and Senate to allow for cross-chamber comparisons. ${ }^{5}$ Augmenting the congressional roll-call matrix votes to include the executives' opinions on the 14 votes (and constraining the item parameters for these votes) and analyzing the resulting matrix using the method of Clinton, Jackman, and Rivers (2004) while constraining four contested conference reports voted on in both the House and Senate to bridge the chambers yields directly comparable ideal point estimates for every legislator, the president, and every federal executive. Consistent with most existing theoretical and empirical work, we assume the policy space for the issues we ask about is unidimensional (Poole and Rosenthal 2007).

In notable contrast to existing estimates of the policy preferences of agencies, our measures can directly compare the policy preferences of various types of federal

\footnotetext{
${ }^{5}$ The estimates were computed using IDEAL 1.03. The space was identified using a mean 0 variance 1 normalization and identical votes across institutions are constrained to have the same item parameters. The 100,000 iterations, thinned by 25 , were estimated and the first 10,000 were discarded as "burn-in." The item parameters for votes on four conference reports (H.Con. Res. 95, HR 2744, HR 4297, and HR 6) are fixed across chambers to "bridge" the estimates.
} 
executives (e.g., appointees versus careerists) to the preferences of legislators and the president (but see Bertelli and Grose 2009, 2011; Nixon 2004). The obvious limitation of the estimates is due to the nature of the data used to estimate comparable policy preferences. Because our survey is the only one that asks about how bureaucrats would vote on issues before Congress, making inferences about the relationship in other times besides the $109^{\text {th }}$ Congress (2005-06) depends critically on how the composition and opinions of those in the bureaucracy might differ from when the survey was conducted. Even so, the general approach we use to generate comparable estimates has far-reaching applicability to other contexts so long as the appropriate questions can be asked. Were other scholars to include similar questions in their surveys, it would be possible to generate similar estimates in the future both in the United States and in other countries.

\section{Ideal Points for Individuals in the Executive Branch}

Comparing the resulting ideal point estimates to the selfreported ideologies and partisanship of the bureaucrats reveals reassuringly strong correlations. Correlating the individual-level responses of self-reported ideology and partisanship to the posterior means of the ideal point estimates reveals correlations of 0.70 and 0.65 (the appendix provides additional comparisons). While the strength of the relationship across the three measures is reassuring, only the ideal point measure provides the ability to compare the ideological distance between political actors on a directly comparable scale. Our measure provides important leverage for both within- and between-agency research designs.

For example, one question that is easily addressed using our measure is whether there is a systematic relationship between the ideology of political appointees and career executives. Are liberal appointees located in bureaucracies with liberal careerists, or are bureaucracies containing liberal careerists more likely to be governed by conservative appointees during the Bush administration? Several works suggest that presidents select conservative appointees to counteract the effect of liberal careerists in the civil service generally or by targeting specific agencies (see, e.g., Aberbach and Rockman 2000; Moe 1985a; Nathan 1975; Weko 1995). Other works find evidence that agencies with liberal missions (i.e., social welfare regulation) attract both careerists and appointees who are more liberal than agencies with more conservative

\section{FIGURE 1 The Relationship between Careerists and Appointees within Agencies Using Three Measures}

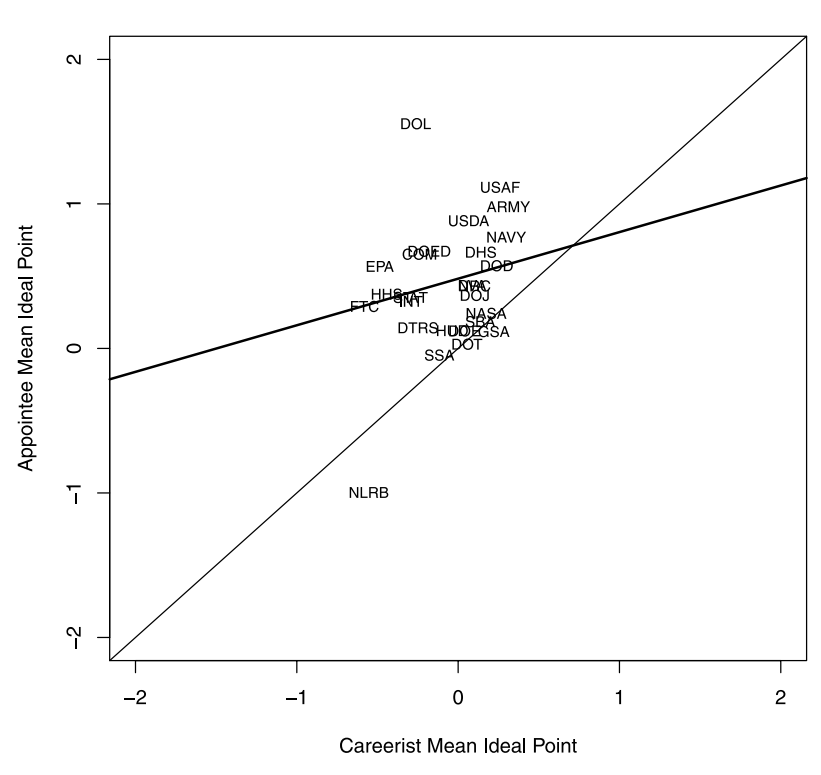

Note: The thin line denotes the 45-degree line and where the within-agency pairings would align if careerists and appointees had identical average ideal points. The bold line is the regression line (weighted by the number of respondents) omitting the one outlier. All agencies with more than 15 respondents are included.

missions (Maranto 1993, 690; Wilson 1989, 261). Lewis (2008), for example, argues that presidents are motivated by both policy and patronage considerations and suggests that conservative patronage-type appointees prefer to take jobs in conservative agencies in Republican administrations and liberal patronage-type appointees prefer jobs in liberal agencies in Democratic administrations. While there are many reasons to suspect either account might be true, our measures provide multiple ways to characterize the relationship. Figure 1 graphs the average preferences of careerists against the average preferences of appointees for each agency containing more than 15 respondents. If appointees are named to particular agencies to counteract the preferences of careerists, the correlation between careerist ideology and appointee ideology should be closer to -1 . If, however, more liberal appointees are selected for more liberal agencies, the correlation between the two sets of preferences should be closer to 1 .

As is evidenced by the distribution of points above the 45-degree line denoting identical policy preferences and the nonzero intercept in the plotted regression line, the average appointee is almost always more conservative than the average careerist across agencies. Consistent with past survey findings, political appointees are ideologically distinctive from career executives and 
closer to the president's (0.85) ideal point (Aberbach and Rockman 2000; Maranto 1993a, 1993b, 2005; Maranto and Hult 2004). Using weighted least squares and weighting by the number of respondents reveals a very imprecise positive relationship between the preferences of careerists and appointees-implying that more liberal appointees are selected for agencies where the average careerist has more liberal preferences and more conservative appointees are selected for agencies containing more conservative careerists. ${ }^{6}$ The relationship evident in Figure 1 suggests that President Bush did not systematically put more conservative appointees into more liberal agencies to counteract their ideological predisposition. ${ }^{7}$ This finding is consistent with the empirical pattern Maranto (1993a) reports and Wilson (1989) suggests but still somewhat surprising given how scholars generally describe presidential administrative strategies. Several works describe an increased presidential focus on ideology in selection, particularly for those agencies that do not share the president's views (e.g., Lewis 2008; Moe 1985a; Nathan 1975; Weko 1995). It is possible that for many agencies, particularly those off the president's agenda, a patronage motivation is driving the appointment pattern (Lewis 2008). The ability to assess such a relationship highlights the importance of scale-comparable estimates of both careerists and appointees for questions such as the strategy behind presidential staffing choices.

The ability to compare policy preferences within an agency is useful and informative, but a more important contribution of the measure is the ability to compare policy preferences across institutions given the number of claims related to the conduct and performance of the bureaucracy that depend critically on the ability to situate the bureaucracy vis-à-vis critical political actors. Figure 2 uses our estimates to characterize the relationship between executive ideal points and the ideal points of members of Congress and President Bush during the $109^{\text {th }}$ Congress (2005-06). ${ }^{8}$ Table 1 provides the associated summary statistics.

${ }^{6}$ The intercept estimate is 0.48 (with a standard error of 0.08 ), and the slope estimate is 0.32 (with a standard error of 0.32 ). The $\mathrm{R}^{2}$ of the regression is 0.04 for the 26 agencies analyzed.

${ }^{7}$ Alternatively, it may also reflect the possibility that some appointee slots are more difficult in a second term of an administrationperhaps especially so in more "liberal" agencies in a conservative Republican administration or in agencies whose work has very little discretion or importance to the administration.

${ }^{8}$ We compare the bureaucrats' ideal points to the political situation when the votes were taken. That is, we compare the ideal points of 2007 bureaucrats to the political situation in 2006. The estimates most clearly speak to the relationship in the $109^{\text {th }}$ Congress (2005-06). Given the relative constancy of the bureaucracy, how-

\section{Figure 2 Distribution of Elite Ideal Points by Institution, 2005-2006}

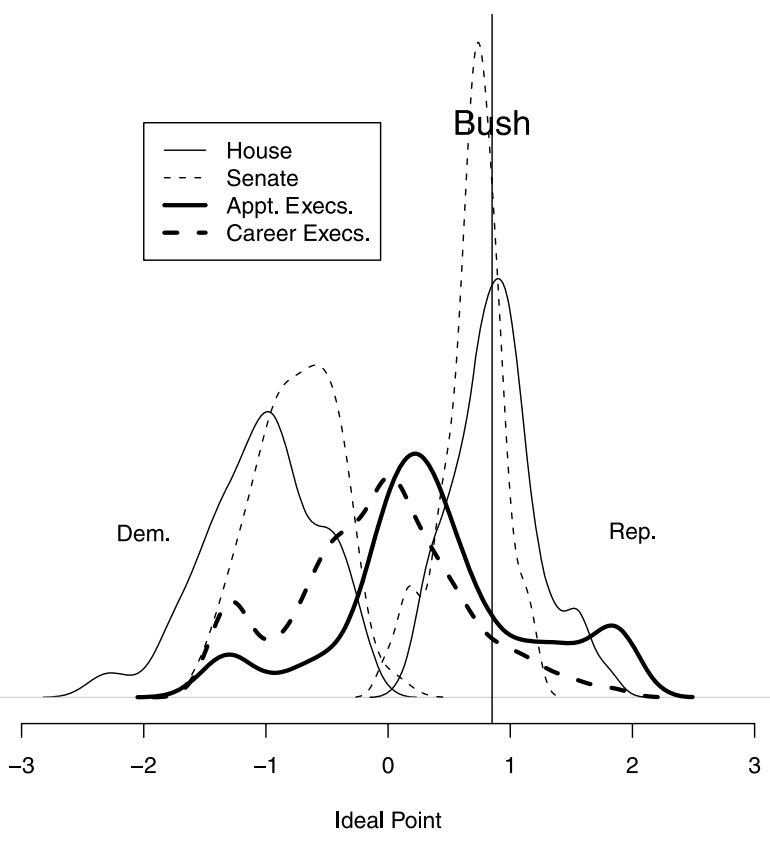

Note: The distribution of ideal points for each labeled group of political elites is plotted. All roll calls are used to estimate ideal points in the House and Senate, votes on contested conference reports are used to "bridge" House and Senate estimates, and 14 votes are used to "bridge" executive and congressional ideal points (seven in each chamber).

Several aspects are worth noting. First, as discussed above, the preferences of appointees are systematically different from those of careerists. Consistent with the pattern in Figure 2, appointees are closer to the Republican Party medians and careerists are closer to the Democratic Party medians. Whereas the median career executive $(-0.05)$ lies within the distribution of ideal points for Democrats in the Senate (whose median is -0.71), the median appointed executive has an estimated ideal point of 0.30 . By way of comparison, President Bush is estimated to have an ideal point of 0.85 and the median Republicans in the House and Senate are 0.86 and 0.73 , respectively. While this is related to the fact that appointees are more likely to be Republicans than careerists in a Republican administration, the heterogeneous nature of bureaucrats' preferences not only has important consequences for many aspects of bureaucratic functioning, but it also likely affects the incentives underlying staffing decisions. The permanent bureaucracy - defined to be the set of career executives-is, on average, quite different from the

ever, it is possible to project the estimates beyond this period so long as we assume that preferences do not vary significantly. 
TABle 1 Ideal Point Estimates for Key Political Actors, 2005-2006

\begin{tabular}{|c|c|c|c|}
\hline Group & Median & $\begin{array}{c}\text { Mean } \\
\text { (Stnd. Err.) }\end{array}$ & $\begin{array}{l}\text { Sample } \\
\text { Size }\end{array}$ \\
\hline President Bush & 0.85 & $\begin{array}{c}0.85 \\
(0.10)\end{array}$ & 1 \\
\hline U.S. Senate & 0.22 & $\begin{array}{r}0.03 \\
(0.07)\end{array}$ & 101 \\
\hline Senate Republicans & 0.73 & $\begin{array}{r}0.68 \\
(0.03)\end{array}$ & 55 \\
\hline Senate Democrats & -0.71 & $\begin{array}{c}-0.75 \\
(0.05)\end{array}$ & 45 \\
\hline U.S. House & 0.34 & $\begin{array}{l}-0.01 \\
(0.05)\end{array}$ & 440 \\
\hline House Republicans & 0.86 & $\begin{array}{c}0.88 \\
(0.02)\end{array}$ & 236 \\
\hline House Democrats & -1.02 & $\begin{array}{c}-1.04 \\
(0.03)\end{array}$ & 203 \\
\hline Career Executives & -0.05 & $\begin{array}{l}-0.10 \\
(0.02)\end{array}$ & 1672 \\
\hline $\begin{array}{l}\text { Republican Career } \\
\text { Executives }\end{array}$ & 0.43 & $\begin{array}{c}0.52 \\
(0.02)\end{array}$ & 472 \\
\hline $\begin{array}{l}\text { Independent Career } \\
\text { Executives }\end{array}$ & 0.03 & $\begin{array}{r}0.07 \\
(0.04)\end{array}$ & 178 \\
\hline $\begin{array}{l}\text { Democratic Career } \\
\text { Executives }\end{array}$ & -0.40 & $\begin{array}{c}-0.45 \\
(0.02)\end{array}$ & 947 \\
\hline $\begin{array}{l}\text { Appointed } \\
\text { Executives }\end{array}$ & 0.30 & $\begin{array}{r}0.37 \\
(0.06)\end{array}$ & 181 \\
\hline $\begin{array}{l}\text { Republican } \\
\text { Appointees }\end{array}$ & 0.42 & $\begin{array}{r}0.65 \\
(0.06)\end{array}$ & 129 \\
\hline $\begin{array}{l}\text { Independent } \\
\text { Appointees }\end{array}$ & -0.19 & $\begin{array}{c}-0.16 \\
(0.16)\end{array}$ & 15 \\
\hline $\begin{array}{l}\text { Democratic } \\
\text { Appointees }\end{array}$ & -0.52 & $\begin{array}{c}-0.52 \\
(0.14)\end{array}$ & 30 \\
\hline
\end{tabular}

Note: The breakdown of Senate Republicans, Senate Democrats, House Republicans, and House Democrats does not sum to the total number of legislators due to independents not displayed. The breakdown of Career and Appointed Executives does not sum to the total number of executives because of missingness in the selfreported partisanship measure.

temporary bureaucracy created by the appointment process. Previous survey research describes how preference divergence between appointees and careerists can have a significant influence on levels of trust, executive turnover, and performance (Aberbach and Rockman 2000; Golden 2000; Maranto 1993a, 1993b, 2005; Maranto and Hult 2004; Michaels 1997).

A second key observation is that while legislator preferences in the House and Senate are bimodal, the distribution of federal executives' preferences in Figure 3 is more concentrated in the center of the ideological space; because the bureaucracy is comprised of Democrats,
Independents, and Republicans, the distribution of ideal points for both career and appointed executives span most of the estimated ideological spectrum. Legislators and presidents may therefore find ideological allies dispersed throughout the bureaucracy. Ideological kinship may be an important source of mutually beneficial relationships, including the distribution of pork, coalitional politics, and congressional or presidential input on civil service promotions (e.g., Arnold 1979; Freeman 1965; Rourke 1969; Wilson 1989).

Our estimates provide a novel and rich characterization of key features of the political environment of bureaucracy. While examining the relationship of careerists and appointees within and across agencies is informative and important for many questions, to assess bureaucratic performance and conduct also requires comparing the policy preferences of agencies to the policy preferences of political actors in other prominent institutions.

\section{Measuring Agency Ideal Points}

Characterizing the relationship between agency preferences and the preferences of political actors is essential for answering many fundamental questions regarding the nature of American politics and political institutions. Despite the importance and usefulness of such measures, two prominent difficulties have stifled progress: the inability to measure policy preferences of agencies and other institutions on a comparable scale and the difficulty of defining what the notion of agency preferences means.

Asking bureaucrats how they would vote on issues before Congress relates the policy preferences of bureaucrats to those of other political actors and addresses the first difficulty. Surmounting the second problem is more complicated because it is not immediately clear how to best aggregate the preferences of individual bureaucrats to measure an agency's policy preference. Whereas the median voter theorem provides a good reason to use medians to characterize preferences in legislatures with unidimensional choice spaces, a similar prediction does not exist for bureaucratic organizations. Should agency preferences be understood as equivalent to those of the agency head(s), or is the agency better thought of as an institution that provides a say to many individuals - perhaps due to the inevitable decentralization and discretion that occurs when implementing the multitude of agency tasks? If the latter, how should we think about the extent to which individual opinions might matter (i.e., the relative voting weights of the bureaucrats)?

Given this ambiguity, we consider two ways of aggregating individual preferences within an agency or bureau. 
The simplest model of agency ideology uses the average preference of the executives working in the agency. This assumes that all opinions within an agency's management team count equally for the determination of agency ideology. More precisely, for agency $j$ with $N_{j}$ respondents consisting of $n_{A}$ appointees and $n_{C}$ careerists, $\bar{X}_{j}=\frac{n_{A}}{N_{j}} \bar{X}_{A}+\frac{n_{C}}{N_{j}} \bar{X}_{C}$ where $\bar{X}_{A}$ and $\bar{X}_{C}$ represent the mean ideal points of appointees and careerists in agency $j$, respectively.

Figure 3 graphs the agency averages arrayed from most liberal to most conservative using the average ideal point in the agency for 2005-06. Each agency ideal point is graphed alongside the estimates of the president and critical actors in Congress (i.e., the median Democrat and Republican in the House and Senate, and the House and Senate median voter). Horizontal lines reflect $95 \%$ credible intervals for the agency averages. Figure 3 reveals that the most conservative agencies are the military services and the Department of Defense (DOD) along with the Department of Homeland Security (DHS). Among the most liberal agencies are regulatory and social welfare agencies, including the National Labor Relations Board (NLRB), the Environmental Protection Agency (EPA), and the Department of Health and Human Services (HHS). Agency preferences almost always lie between the preferences of the median Democrat and Republican in both the House and Senate, but few of the agency means are as extreme as the party medians. That said, the preferences of the military services, DOD, and DHS are much closer to the preferences of the Republicans in the House and Senate than HHS or EPA. The estimates generally confirm what previous survey research has suggestedexecutives in defense agencies are significantly more conservative than executives working in social welfare or regulatory agencies (Aberbach and Rockman 2000; Clinton and Lewis 2008; Maranto 1993a, 1993b; Maranto and Hult 2004).

A potential shortcoming of using the sample mean to measure agency preferences is it ignores potential differences in how important careerists and appointees are for determining agency preferences. It also does not account for the higher nonresponse rate among appointees. To relax these assumptions, we construct respondent weights using the reported relative influence of appointees and careerists in agency policy decisions. All respondents to the Survey on the Future of Government Service were asked, "In general, how much influence do the following groups have over policy decisions in your agency?" with a response set of "A great deal," "A good bit," "Some," "Little," "None," and "Don't Know" for appointees and senior civil servants. We use the responses to weight the ideal points of appointees by the percentage of respondents in the
FIGURE 3 Unweighted Estimates of Mean Ideology in an Agency (and 95\% Credible Intervals)

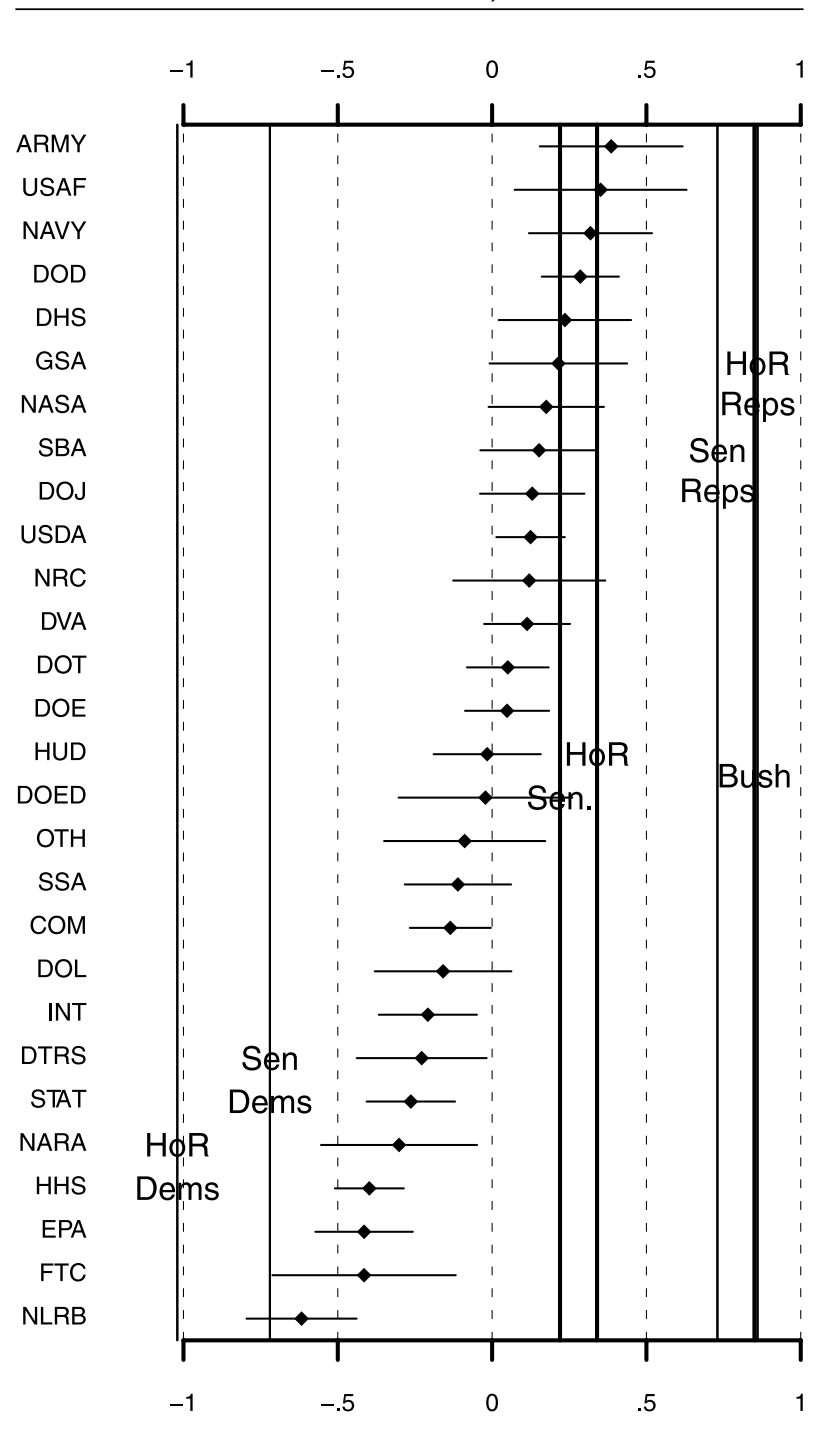

Note: The points denote the average ideal point for executives in an agency if the agency contains at least 15 respondents, and the horizontal lines denote the $95 \%$ credible interval for the estimated mean. The vertical lines denote the median of the House, Senate, House Democrats, Senate Democrats, House Republicans, Senate Republicans, and the ideal point of President Bush.

agency who believe appointees exercise "A great deal" or "A good bit" of influence over the total percentage giving these responses for both appointees and careerists in the agency. More precisely, if a proportion of respondents $p$ report that appointees exert "A great deal" or "A good bit" of influence over agency decisions in agency $j$ and a proportion $k$ report that senior civil servants exert "A great deal" or "A good bit" of influence over agency decisions in agency $j$, we weight the average ideal point of appointee respondents by $p /(p+k)$ and the average ideal 
point of careerist respondents by $k /(p+k)$. For agency $j$, the agency's ideal point is $\bar{X}_{j}=\frac{p}{p+k} \bar{X}_{A}+\frac{k}{p+k} \bar{X}_{C}$ and every term on the right-hand side is specific to agency $j$.

Weighting appointee and careerist means by perceived influence helps ameliorate potential concerns that might arise due to the lower response rate among appointees because the weight is a function of perceived influence rather than sample composition. Given the nature of the weight, we term the resulting weight the influence weight. The average influence weight for appointees is 0.56 - reflecting the fact that, on average, respondents believe that political appointees have more influence over policy outcomes than careerists. There is variation in the weights, however, as some agencies have almost equal influence (e.g., the Department of Defense and the Nuclear Regulatory Commissions have influence weights for appointees of 0.52 and 0.51 , respectively), and the responses in some agencies suggest that appointees have considerably more influence (e.g., the Department of Interior at 0.57 , the State Department at 0.58, and the Department of Education at 0.66). Of the agencies with at least 15 respondents, only the National Archives and Record Administration reported that careerists were more influential than appointees (with an appointee influence weight of only 0.33 ).

Figure 4 graphs the relationship between the two measures of agency preference and reveals some differences in the influence-weighted means relative to the unweighted means; some agencies are slightly more conservative (e.g., the Environmental Protection Agency, labeled "EPA," and the Department of Labor, labeled "DOL") and some slightly more liberal (e.g., the National Labor Relations Board, labeled "NLRB"). The agency ideal point estimates using the influence weights contain the same variation as is evident in the unweighted estimates (the means correlate at 0.70 ), but the ideological location of agencies generally shifts in a conservative direction. Because of the Republican president at the time of the survey and the greater influence attributed to political appointees, the agencies are estimated to be more conservative using influence weights. ${ }^{9}$ Because our estimates identify which agencies are liberal and which agencies are conservative relative to other political actors, our estimates provide an important new resource for testing theories of

${ }^{9}$ To make the effect more precise, we also regress the influenceweighted mean on the unweighted mean (weighting by the number of respondents in each agency). As Figure 4 reveals, not only are agencies systematically more conservative (the regression intercept is 0.31 with a standard error of 0.04 ), but the slope coefficient of 0.85 (standard error of 0.18 ) reveals that the ideological variation across agencies in the unweighted means is relatively preserved when using the influence weights. (The $\mathrm{R}^{2}$ for the regression on the 26 agencies is 0.49 .)

\section{FIgURE 4 The Relationship between Unweighted Agency Ideal Points and Influence Weighted Agency Ideal Points}

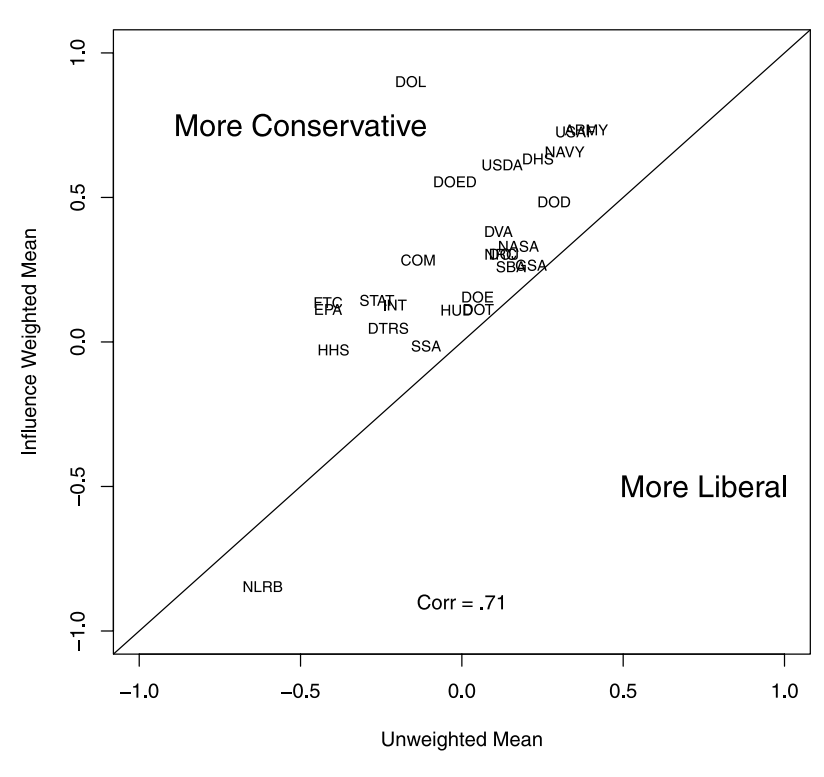

Note: The labels denote the mean ideal point of respondents in the agency weighting all respondents equally (Unweighted Mean) and weighting by the relative influence of appointees and careerists in the agency (Influence Weighted Mean). The agency means correlate at 0.71 . The 45 -degree line denotes where the influence-weighted means and unweighted means would align if their ideal points were the same.

political institutions. They also highlight how one's implicit model of agency decision making is fundamental to empirically evaluating models of delegation, separation of powers, and bureaucratic control. Assuming agency ideal points are influenced more by careerists than appointees or vice versa has important consequences for the ideological location of agencies in relation to political principals such as the president or chamber medians.

In total, our measures allow the investigation of critical questions such as which agencies share the preferences of the president versus Congress and how agency ideology influences appointment strategies. We now illustrate how our estimates of agency preferences can help evaluate theories of American politics and political institutions.

\section{Application: Delegation and Discretion in the $109^{\text {th }}$ Congress}

In an influential article, Gailmard and Patty (2007) model the choice of a legislature to offer discretion to an executive agency - and the choice of a civil servant to 
continue to work at the agency or to leave the agency for private employment-in a two-period game. They argue that the amount of discretion offered by the legislature is contingent upon the size of the ideological distance between the legislature and the agency. In their model, Congress wants an agency that is more likely to implement its preferred policy and possess policy expertise. In equilibrium, agencies employ bureaucrats motivated by policy, and only the policy-motivated bureaucrats who remain in the agency over time develop expertise. Because these agents have employment options outside government, if wages are better in the private sector the only incentive the agent has for remaining in public service is influence over policy. The central nonmonetary incentive is the ability for the agent-via increased discretion-to move policy closer to his or her own ideal point. Given the potential threat of exit from the civil service, Congress grants more discretion to the agent as the ideological distance between it and its agents grows to provide incentives for policy expertise - until the distance between Congress and agency becomes too large. At some point the ideological distance between the legislature and the agency is so great that Congress will become more concerned with the extreme policy outcomes that the agency might implement. Gailmard and Patty (2007) therefore predict that the ideological distance between Congress and agencies has a nonlinear influence on discretion: discretion is initially increasing in ideological distance between the agency and Congress but ultimately decreasing once the distance passes a certain threshold.

The article includes some additional testable implications worth mentioning. Briefly, if the legislature is very certain about the location of the implemented policy, then it grants less discretion to the agency. In addition, it is expected that more discretion will be granted to agencies with greater expertise.

To test these predictions, we examine the amount of discretion Congress granted to agencies in public laws enacted during the time period of the survey (2005-07). Of the 482 public laws enacted during the $109^{\text {th }}$ Congress, we were able to identify the agency with primary jurisdiction in 208 laws. ${ }^{10}$ Our unit of analysis is a public law. The variation of interest is the amount of discretion granted by Congress to an agency in each public law. Although a

\footnotetext{
${ }^{10}$ We match public laws to an agency by first identifying all Senate and House committees to which the bill was referred. We matched each agency to the committee to which the bill was referred based upon which Senate committee (and House committee equivalent) processes the nomination of the agency head. In cases where jurisdictions covered multiple agencies (e.g., Energy and Commerce) we determined the frequency an agency appeared in the text of legislation, and the agency appearing the most times in the text was matched to the public law.
}

difficult concept to measure, we follow Huber and Shipan (2002) and use the logarithm of the number of words in each public law as the dependent variable. According to Huber and Shipan, laws with short texts leave ample room for discretion, while "longer statutes. . are more likely to tell agencies what to do" $(2002,73)$. Larger values of the dependent variable are therefore assumed to indicate less discretion; the measurement assumption is that more words are required to constrain than delegate. One might quibble with this measure, but our purpose in using an existing measure is to demonstrate the importance of our measure of agency preferences for answering important outstanding questions.

A serious difficulty faced by prior investigations into the amount of discretion legislatures provide to agencies is the inability to directly compare the policy preferences of legislators and agencies. Scholars have measured ideological distance between the legislature and the executive branch using coarse indicators such as the presence of divided government (Epstein and O'Halloran 1999; Huber and Shipan 2002). These measures may provide a useful proxy for preference divergence when examining discretion over time, but the measure assumes all agencies within a presidential regime have identical ideological profiles. While this assumption may be reasonable for the 50 states (e.g., Huber and Shipan 2002), the variation in agency preferences in Figure 3 clearly challenges this assumption at the federal level.

To test the effects of ideological proximity between Congress and agencies as predicted by the Gailmard-Patty model, we utilize the agency ideal points discussed in the fourth section. The variable Agency-floor distance is measured using $\left|X_{A}-X_{H}\right|$, where $X_{A}$ is the ideal point estimate of the agency and $\mathrm{X}_{\mathrm{H}}$ is the ideal point estimate of the House median (using the closest chamber median provides substantively identical results). Squared agency-floor distance is $\left|\mathrm{X}_{\mathrm{A}}-\mathrm{X}_{\mathrm{H}}\right|^{2}$. Because discretion is measured using the number of words in each public law and longer texts are assumed to provide less discretion, the Agencyfloor distance variable should be negative-greater distance yields more discretion and therefore fewer words in the text of the statute. However, the squared variable should be positively related to the log of the number of words in the public statute as more words (less discretion) are expected when ideological distance is very large. Given the above discussion regarding the meaning of agency ideology, we use three measures to characterize the policy preferences of agencies: the average ideal point in an agency, the average ideal point for careerists in an agency, and the influence-weighted agency ideal point.

Policy certainty is measured using the proportion of distinct programs in each agency that have valid 
TABle 2 Predicting the Extent of Agency Discretion by the $109^{\text {th }}$ Congress (2005-2006)

\begin{tabular}{lccc}
\hline $\begin{array}{l}\text { Predicting Agency Discretion } \\
\text { (higher values = less discretion) }\end{array}$ & $\begin{array}{c}\text { Model 1 } \\
\text { All Respondents } \\
\text { Coef. (s.e.) }\end{array}$ & $\begin{array}{c}\text { Model 2 } \\
\text { Careerists Only } \\
\text { Coef. (s.e.) }\end{array}$ & $\begin{array}{c}\text { Model 3 } \\
\text { Influence Weights } \\
\text { Coef. (s.e.) }\end{array}$ \\
\hline Agency-floor distance $\left|X_{A}-X_{H}\right|$ & $-14.31^{* *}$ & $-14.13^{* *}$ & $-13.35^{*}$ \\
& $(6.77)$ & $(6.71)$ & $(8.52)$ \\
Agency-floor distance squared $\left|X_{A}-X_{H}\right|^{2}$ & $14.46^{* *}$ & $13.01^{* *}$ & $26.19^{*}$ \\
& $(6.69)$ & $(5.87)$ & $(16.13)$ \\
Policy certainty & 1.03 & $1.59^{*}$ & 1.10 \\
& $(0.96)$ & $(0.97)$ & $(1.03)$ \\
Expertise (prop. technical) & 0.86 & 1.58 & -0.05 \\
& $(1.57)$ & $(1.59)$ & $(1.88)$ \\
Expertise (prop. professional) & -1.97 & -2.30 & -0.21 \\
Constant & $(2.14)$ & $(2.20)$ & $(1.58)$ \\
& $9.65^{* *}$ & $9.37^{* *}$ & $7.20^{* *}$ \\
$R^{2}$ & $(2.47)$ & $(2.27)$ & $(1.74)$ \\
$N$ & 0.24 & 0.24 & 0.23 \\
\hline
\end{tabular}

Note: The unit of analysis is the public law. Each model is estimated with OLS with robust standard errors clustered on the agency. $\mathrm{X}_{\mathrm{A}}=$ Ideal point estimate of agency using the indicated measure. $\mathrm{X}_{\mathrm{H}}=$ Ideal point estimate of the House median. ${ }^{* *} \mathrm{p} \leq 0.05$; ${ }^{*} \mathrm{p} \leq 0.10$ in one-tailed tests. Policy area indicator estimates omitted. Descriptive statistics are reported in the online appendix.

performance measures. A sample of programs in each agency was assessed each fiscal year as part of the budgetary process during the Bush administration. These assessments evaluated, among other things, whether programs have adequate performance measures with an emphasis on measuring outcomes rather than outputs. Situations where performance measures are unavailable are situations where it is difficult for executives and legislators to determine the relationship between agency outputs and outcomes and where it is harder to determine how legislative mandates will affect outcomes. Agencies with a higher percentage of programs with appropriate performance measures suggest increased policy certainty (and therefore less discretion). We measure policy expertise in each agency using the Proportion of technical and Proportion of professional employees and include indicators for policy areas to account for variation in statute length due to policy differences. ${ }^{11}$

Table 2 reports the results of the statistical model using the three measures of agency policy preferences. The substantive effects are nearly identical, and the estimates are consistent with the predictions of Gailmard and Patty (2007); the distance between the floor and the agency is correlated with fewer words-and there-

\footnotetext{
${ }^{11}$ Source: Performance data from FY2005 budget (www.omb.gov); September 2005 personnel data from OPM website (fedscope. opm.gov); policy data from www.policyagendas.org.
}

fore presumably more discretion-up to a certain point, but discretion decreases as the distance between agency and the pivotal floor actor in Congress gets very large (as evidenced by the positive coefficients for Squared agencyfloor distance in the models). Substantively, changing the amount of preference divergence from no divergence to the average amount decreases the predicted number of words (and therefore increases discretion) by about 3.5\% in Model 1. Increasing preference divergence from the average amount to the maximum amount, however, increases the number of words and decreases discretion by about $1.4 \%$. Models 2 and 3 produce similar patterns except the magnitude of the effects differ. In Model 2, for example, increasing preference divergence is estimated to increase discretion except for the highest observed values.

As expected, model estimates suggest that Policy certainty leads to less legislative discretion, although the estimates are imprecise and the substantive effects are small. Increasing the proportion of programs with adequate performance measures by $10 \%$ is estimated to increase the number of words from one-tenth of $1 \%$ to one-seventh of $1 \%$. We could not reject the null that agency expertise, as measured by the proportion of technical or professional employees, has no effect on agency discretion.

Overall, our results are generally supportive of the comparative-static predictions of Gailmard and Patty (2007), particularly with regard to preference divergence. 
The ability to directly measure policy divergence across agencies and relate the evident preference divergence to the actions of political elites in a theoretically interpretable fashion provides but one example of how our measures can help illuminate and refine the relationships that exist in the theoretically rich literature on bureaucratic politics.

\section{Discussion and Conclusion}

Government agencies are fundamentally political. The persons that populate the departments and agencies of the federal government organize, lobby, and make public policy like other political actors. Understanding administrative agencies and the decision makers inside them is crucial for the study of American politics. Yet, it has been difficult to study these political actors and their agencies because of our inability to measure their policy views in a way that is comparable to those of other political entities. We present a new method for estimating the preferences of federal executives and their agencies, and we help illuminate a number of features of the political-administrative system. For example, our estimates confirm that the preferences of career professionals differ from political appointees (Aberbach and Rockman 2000; Maranto 1993a, 1993b, 2005; Maranto and Hult 2004). Indeed, many career professionals were more liberal than their appointee counterparts as well as congressional Republicans and the president during the $109^{\text {th }}$ Congress. The estimates also suggest, somewhat surprisingly, that the president tends to appoint more liberal appointees to liberal agencies and more conservative appointees to conservative agencies rather than use appointees to counterbalance the ideological leanings of agencies. Although the nature of the data means that we cannot rule out alternative explanations (e.g., the potential difficulty of a Republican administration filling appointments in a "liberal" agency in their second term), this relationship is contrary to the notion that presidents strategically politicize those agencies with views most dissimilar from their own and suggests some combination of policy and patronage concerns influence appointments (Lewis 2008; Nathan 1975).

While our estimates provide important new information about which agencies are liberal and which are conservative in ways that differ from existing views, the critical contribution is the ability to compare how different agencies compare to key political officials in Congress and the White House-perhaps the key factor in many models of separation of powers and the bureaucracy. We find that most agencies were more liberal than the pres- ident and chamber medians and only the most conservative agencies such as the military services were more conservative than the chamber medians.

The estimates are important because, as our analysis of Gailmard and Patty (2007) suggests, arguments about preference divergence are essential to many models of bureaucracy and our estimates provide scholars a means of measuring the extent of preference divergence among different political actors. For example, an important argument in the institutions literature concerns the ally principle-i.e., whether political actors delegate more to agents who share their preferences (Bendor and Meirowitz 2004; Boehmke, Gailmard, and Patty 2005). A similarly important literature evaluates whether advice or signals are more likely to be accepted when actors share preferences (Krehbiel 1991; Patty 2009). Testing arguments about the ally principle or signaling in a separation of powers context requires estimates of the preferences of the actors involved.

While our estimates concern the administrative state in the United States at a particular point in time, the method we use to generate estimates of executive and agency preferences can be applied to different contexts and over time. While extending the temporal domain of the estimates we present requires using additional information (and assumptions) about how the bureaucracy might differ from the circumstances in which the survey was conducted, political scientists have routinely surveyed executive officials in different contexts and times (e.g., Aberbach and Rockman 2000; Aberbach, Putnam, and Rockman 1981; Golden 2000; Maranto 1993a, 1993b, 2005; Maranto and Hult 2004; Meier and Nigro 1976; Michaels 1997). We demonstrate how the addition of a few questions to these surveys can help measure the administrative policy preferences in different countries and across time. Such new data would further improve our understanding of the increasingly important administrative political institutions in the United States and elsewhere.

\section{References}

Aberbach, Joel D. 1990. Keeping a Watchful Eye. Washington, DC: Brookings Institution Press.

Aberbach, Joel D., Robert D. Putnam, and Bert A. Rockman. 1981. Bureaucrats and Politicians in Western Democracies. Cambridge, MA: Harvard University Press.

Aberbach, Joel D., and Bert A. Rockman. 1976. "Clashing Beliefs within the Executive Branch: The Nixon Administration Bureaucracy." American Political Science Review 70(2): 456-68.

Aberbach, Joel D., and Bert A. Rockman. 2000. In the Web of Politics. Washington, DC: Brookings Institution Press. 
Arnold, R. Douglas. 1979. Congress and the Bureaucracy. New Haven, CT: Yale University Press.

Bafumi, Joseph, and Michael C. Herron. 2010. "Leapfrog Representation and Extremism: A Study of American Voters and Their Members of Congress." American Political Science Review 104(3): 519-42.

Bailey, Michael A. 2007. "Comparable Preference Estimates across Time and Institutions for the Court, Congress, and Presidency." American Journal of Political Science 51(3): 433-48.

Bendor, Jonathan, and Adam Meirowitz. 2004. "Spatial Models of Delegation." American Political Science Review 98(2): 293-310.

Bertelli, Anthony M. 2010. "Congressional Ideology and Administrative Oversight." Historical Methods 43(3):125-37.

Bertelli, Anthony, and Sven E. Feldmann. 2007. "Strategic Appointments." Journal of Public Administration Research \& Theory 17(1): 19-38.

Bertelli, Anthony M., and Christian R. Grose. 2006. "The Spatial Model and the Senate Trial of President Clinton." American Politics Research 34(4): 535-59.

Bertelli, Anthony M., and Christian R. Grose. 2007. "Agreeable Administrators? The Public Positions of Cabinet Secretaries and Presidents." Presidential Studies Quarterly 37(2): 228-47.

Bertelli, Anthony M., and Christian R. Grose. 2009. "Secretaries of Pork? A New Theory of Distributive Politics." Journal of Politics 71(3): 926-45.

Bertelli, Anthony M., and Christian R. Grose. 2011. "The Lengthened Shadow of Another Institution? Ideal Point Estimates for the Executive Branch and Congress." American Journal of Political Science 55(4): 767-81.

Boehmke, Frederick J., Sean Gailmard, and John W. Patty. 2005. "Whose Ear to Bend? Information Sources and Venue Choice in Policy-Making." Quarterly Journal of Political Science 1(2): 139-69.

Carpenter, Daniel P. 2001. The Forging of Bureaucratic Autonomy. Princeton, NJ: Princeton University Press.

Clinton, Joshua D. 2006. "Representation in Congress: Constituents and Roll Calls in the 106th House," Journal of Politics 68(2): 397-409.

Clinton, Joshua D., Simon Jackman, and Doug Rivers. 2004. "The Statistical Analysis of Roll Call Voting: A Unified Approach." American Political Science Review 98(2): 355-70.

Clinton, Joshua D., and David E. Lewis. 2008. "Expert Opinion, Agency Characteristics, and Agency Preferences.” Political Analysis 16(1): 3-20.

Cohen, Jeffrey E. 1986. “The Dynamics of the 'Revolving Door' on the FCC." American Journal of Political Science 30(4): 689-708.

Epstein, David, and Sharyn O'Halloran. 1999. Delegating Powers. New York: Cambridge University Press.

Epstein, Lee, Andrew D. Martin, Jeffrey A. Segal, and Chad Westerland. 2007. “The Judicial Common Space.” Journal of Law, Economics, and Organization 23(2): 303-25.

Freeman, J. Leiper. 1965. The Political Process. New York: Random House.
Gailmard, Sean, and John W. Patty. 2007. "Slackers and Zealots: Civil Service, Policy Discretion, and Bureaucratic Expertise." American Journal of Political Science 51(4): 873-99.

Gilmour, John B., and David E. Lewis. 2006. "Political Appointees and the Competence of Federal Program Management." American Politics Research 34(1): 22-50.

Golden, Marissa Martino. 2000. What Motivates Bureaucrats? New York: Columbia University Press.

Grose, Christian R. 2011. Congress in Black and White: Race and Representation in Washington and at Home. New York: Cambridge University Press.

Huber, John D., and Charles R. Shipan. 2002. Deliberate Discretion? New York: Cambridge University Press.

Jessee, Stephen. 2009. "Spatial Voting in the 2008 Presidential Election." American Political Science Review 103(1): 59-81.

Jessee, Stephen. 2010. "Partisan Bias, Political Information and Spatial Voting in the 2008 Presidential Election." Journal of Politics 72(2): 327-40.

Krehbiel, Keith. 1991. Information and Legislative Organization. Ann Arbor: University of Michigan Press.

Lewis, David E. 2008. Politics of Presidential Appointments. Princeton, NJ: Princeton University Press.

Maranto, Robert. 1993a. "Still Clashing after All These Years: Ideological Conflict in the Reagan Executive." American Journal of Political Science 37(3): 681-98.

Maranto, Robert. 1993b. Politics and Bureaucracy in the Modern Presidency. Westport, CT: Greenwood Press.

Maranto, Robert. 2005. Beyond a Government of Strangers. Lanham, MD: Lexington Books.

Maranto, Robert, and Karen M. Hult. 2004. "Right Turn? Political Ideology in the Higher Civil Service, 1987-1994." American Review of Public Administration 34(2): 199-222.

Martin, Andrew D., and Kevin M. Quinn. 2002. "Dynamic Ideal Point Estimation via Markov Chain Monte Carlo for the U.S. Supreme Court, 1953-1999.” Political Analysis 10: 134-53.

Michaels, Judith E. 1997. The President's Call: Executive Leadership from FDR to George Bush. Pittsburgh, PA: University of Pittsburgh Press.

McCarty, Nolan M., and Keith T. Poole. 1995. "Veto Power and Legislation: An Empirical Analysis of Executive and Legislative Bargaining from 1961 to 1986." Journal of Law, Economics, and Organization 11(2): 282-312.

McCubbins, Mathew D., Roger Noll, and Barry Weingast. 1987. "Administrative Procedures as Instruments of Political Control." Journal of Law, Economics, and Organization 3(2): 243-77.

McCubbins, Mathew D., Roger Noll, and Barry Weingast. 1989. "Structure and Process, Politics and Policy: Administrative Arrangements and the Political Control of Agencies." Virginia Law Review 75(2): 431-82.

McCubbins, Mathew D., and Thomas Schwartz. 1984. "Congressional Oversight Overlooked: Police Patrol versus Fire Alarm." American Journal of Political Science 28(1): 165-77.

Meier, Kenneth John, and Lloyd G. Nigro. 1976. "Representative Bureaucracy and Policy Preferences: A Study in the Attitudes of Federal Executives." Public Administration Review 36(4): 458-69. 
Moe, Terry M. 1985a. "The Politicized Presidency.” In The New Direction in American Politics, ed. J. E. Chubb and P. E. Peterson. Washington, DC: Brookings Institution Press, 235-71.

Moe, Terry M. 1985b. Control and Feedback in Economic Regulation: The Case of the NLRB. American Political Science Review 79(4): 1094-1116.

Nathan, Richard P. 1975. The Plot That Failed: Nixon and the Administrative Presidency. New York: John Wiley.

Nixon, David C. 2004. "Separation of Powers and Appointee Ideology." Journal of Law, Economics, and Organization 20(2): 438-57.

Patty, John W. 2009. “The Politics of Biased Information.” Journal of Politics 71: 385-97.

Poole, Keith. 1998. "Estimating a Basic Space from a Set of Issue Scales." American Journal of Political Science 42(3): 95493.

Poole, Keith, and Howard Rosenthal. 2007. Ideology and Congress. New Brunswick, NJ: Transaction Press.
Rourke, Francis. 1969. "Variations in Agency Power." In Bureaucratic Power in National Politics, ed. Francis E. Rourke. Boston: Little, Brown, 240-62.

Snyder, Susan K., and Barry R. Weingast. 2000. "The American System of Shared Powers: The President, Congress, and the NLRB." Journal of Law, Economics, and Organization 16(2): 269-305.

Treier, Shawn. 2010. "Where Does the President Stand? Measuring Presidential Ideology." Political Analysis 18(1): 124-36.

Weingast, Barry W., and Mark J. Moran. 1983. "Bureaucratic Discretion or Congressional Control? Regulatory Policymaking by the Federal Trade Commission." Journal of Political Economy 91(5): 765-800.

Weko, Thomas J. 1995. The Politicizing Presidency. Lawrence: University Press of Kansas.

Whitford, Andrew B. 2005. "The Pursuit of Political Control by Multiple Principals.” Journal of Politics 67(1): 29-49.

Wilson, James Q. 1989. Bureaucracy. New York: Basic Books.

Wood, B. Dan, and Richard W. Waterman. 1994. Bureaucratic Dynamics. Boulder, CO: Westview Press. 